\title{
Three Weights of Lampsacus
}

\section{Oğuz Tekin}

\section{OpenEdition}

\section{Journals}

\section{Electronic version}

URL: http://journals.openedition.org/anatoliaantiqua/296

DOI: 10.4000/anatoliaantiqua.296

\section{Publisher}

IFEA

\section{Printed version}

Date of publication: 1 January 2014

Number of pages: 155-158

ISBN: 9782362450136

ISSN: 1018-1946

\section{Electronic reference}

Oğuz Tekin, «Three Weights of Lampsacus », Anatolia Antiqua [Online], XXII | 2014, Online since 30 June 2018, connection on 18 December 2020. URL : http://journals.openedition.org/anatoliaantiqua/ 296 ; DOI : https://doi.org/10.4000/anatoliaantiqua.296 


\section{ANATOLIA ANTIQUA ESKI ANADOLU}

\section{XXII}

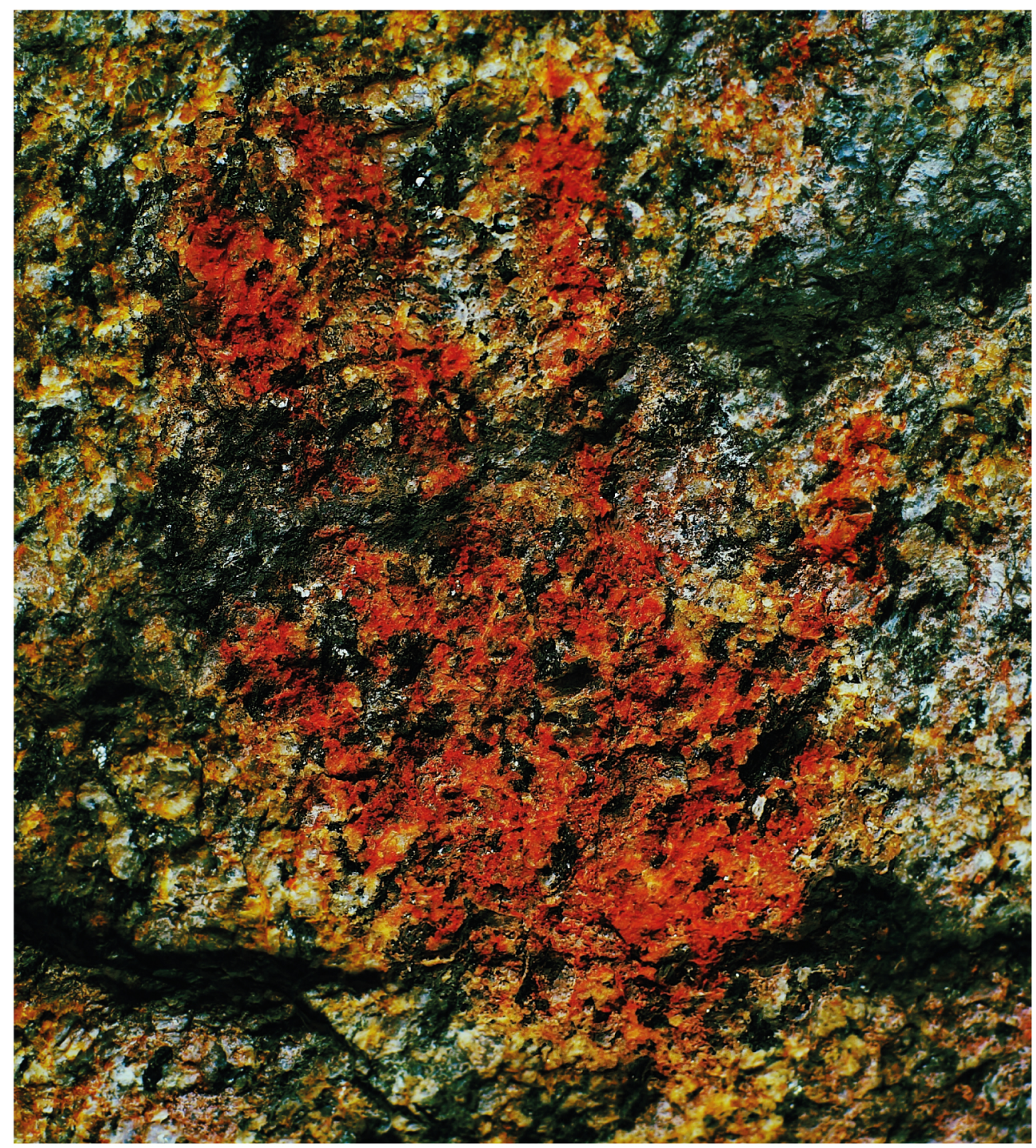

INSTITUT FRANÇAIS D'ETUDES ANATOLIENNES GEORGES-DUMEZIL CNRS USR 3131

DE BOCCARD 


\section{TABLE DES MATIERES}

Emma BAYSAL,

A preliminary typology for beads from the Neolithic and Chalcolithic levels of Barcın Höyük

William ANDERSON, Jessie BIRKETT-REES, Michelle NEGUS CLEARY,

Damjan KRSMANOVIC et Nikoloz TSKVITINIDZE,

Archaeological survey in the South Caucasus (Samtskhe-Javakheti, Georgia):

Approaches, methods and first results

Eda GÜNGÖR ALPER,

Hellenistic and Roman period ceramic finds from the Balatlar Church excavations in

Sinop between 2010-2012

Ergün LAFLI et Gülseren KAN ŞAHİN,

Hellenistic ceramics from Southwestern Paphlagonia

Oğuz TEKIN,

Weights of Lysimachea from the Tekirdağ Museum and various collections

Oğuz TEKIN,

Three weights of Lampsacus

Julie DALAISON et Fabrice DELRIEUX,

La cité de Néapolis-Néoclaudiopolis : histoire et pratiques monétaires

Martine ASSENAT et Antoine PEREZ,

Amida 4. Constance II et Amida

Sencan ALTINOLUK et Nilüfer ATAKAN,

Abrasax: A magical gem in the Istanbul Archaeological Museums

Bahadır DUMAN,

A group of local production Middle Byzantine period pottery from Tripolis:

'Micaceous White Painted Ware'

CHRONIQUES DES TRAVAUX ARCHEOLOGIQUES EN TURQUIE, 2014

Jean-Charles MORETTI,

avec la collaboration de Nicolas BRESCH, Isabel BONORA, Jean-Jacques MALMARY et

Olivier RISS,

Claros, le Temple d'Apollon : travaux réalisés en 2013

Suat ATEŞLIER,

On the excavations of the Zeus Temple of Alabanda 
Olivier HENRY,

avec Ayşe Güliz BİLGIN ALTINÖZ, Jesper BLID, Ömür Dünya ÇAKMAKLI, Andrew DUFTON, Agneta FRECCERO, Linda GOSNER, Ragnar HEDLUND, Pascal LEBOUTEILLER,

Vasilica LUNGU, Felipe ROJAS, Fredrik TOBIN, Baptiste VERGNAUD et

Andrew WATERS,

La mission Labraunda 2013 - Rapport préliminaire

Dominique BEYER, Isabelle CHALIER, Françoise KIRNER,

Françoise LAROCHE-TRAUNECKER et Aksel TIBBET,

Zeyve Höyük - Porsuk. Rapport préliminaire sur la campagne 2013

Çiğdem MANER,

Preliminary report on the first season of the Konya-Ereğli (KEYAR) survey 2013 


\section{Oğuz TEKİN*}

\section{THREE WEIGHTS OF LAMPSACUS}

Located on the southern coast of the Sea of Marmara near the Dardanelles, Lampsacus (the modern-day Lapseki) was settled by colonists from Phocaea (Foça) and Miletus. Under the control, successively, of Lydia and Persia, Lampsacus paid a tax of 12 talents (approximately $300 \mathrm{~kg}$ of silver) to the Delian League established by Athens to counteract the Persian threat. The city also minted gold coins in the $4^{\text {th }}$ century B.C., which was a rarity for Anatolian cities in the Classical and Hellenistic periods. Both the large tax paid by the city to the Delian League and the fact that it minted gold coins indicates that Lampsacus was among the region's wealthiest cities. The city was also the home of Priapus, a god of fertility and reproduction, as well as producing a number of philosophers who put their print on the intellectual world of their time.

Lampsacus began to mint coins in the early $5^{\text {th }}$ century B.C., with its earliest electrum staters and then gold ones being known as Lampsakenoi. The city continued minting throughout the Classical and Hellenistic periods, but it did not mint only its own coins: it was one of the mints of Alexander the Great ${ }^{1}$ and after the death of Alexander the Great, it also produced coins in the name of King Lysimachus ${ }^{2}$, who ruled in Thrace and in the Marmara region. Lysimachus, like Alexander's other successors, copied the images used on coins minted in Alexander's time, thus continuing to produce Alexander's coins even after his death.
On the coins of Lampsacus, there are various types but the common type is the Hippalectryon, which occurs frequently on Lampsacene coins ${ }^{3}$. So this type, Hippalectryon, was also used as a symbol on the market weights of Lampsacus. This type was also used by Adramyteum on its coins ${ }^{4}$, so the attribution of every weight bearing a Hippalectryon to Lampsacus is not certain since these weights do not bear the ethnic on them. The following three weights are from various collections: while the first one is from Germanisches Zentralmuseum at Mainz, the other two are from a private collection in Şarköy (Edirne) $)^{5}$; none of them were published previously.

The first weight (Fig. 1) ${ }^{6}$ is almost a thick square in form with bevelled edges but the bottom is larger than the top; it measures $32 \times 30 \times 11 \mathrm{~mm}$ and weighs $122.5 \mathrm{~g}$. On the obverse is a Hippalectryon facing left with curved right; below, the denominational mark T which stands for $\tau \varepsilon \dot{\tau} \alpha \rho \tau o v$, all in relief. The reverse is blank. It is a tetarton, i.e. quarter mna (mna of $490 \mathrm{~g}$ ). Although the exact find place is unknown, it is stated in the inventory book that this weight was bought from a private collector in Istanbul in 1984.

The second weight (Fig. 2) 7 is square in form too. It measures $26 \times 25 \times 11 \mathrm{~mm}$ and weighs $66.1 \mathrm{~g}$. On the obverse there is an Hippalectryon facing left as the previous one. The figure is worn. We can not be sure of its denomination since there is no denom-

*) Istanbul University, Ancient History Department, Beyazıt-İstanbul. E-mail: tekinotekin@yahoo.com.

1) Thompson 1991.

2) Thompson 1968: $170 \mathrm{ff}$.

3) For the Hippalectryon on the Lampsacene electrum, gold, silver and bronze coins see Baldwin 1924, esp. Plates I-III; BMC Mysia, $\mathrm{n}^{\text {os }} 1-9 ; 23-31 ; 46-49 ; 50-67$. But unfortunately, this creature is misdescribed as Pegasus in the above mentioned publications although it is a Hippalectryon with its rooster tail.

4) Fritze 1910: pl. I, $\mathrm{n}^{\text {os }} 1-5$; Gaebler 1924: pl. XVIII, $\mathrm{n}^{\text {os }}$ 1-12; Stauber 1996: $\mathrm{n}^{\text {os }} 11-15$ (many examples).

5) I would like to thank Falko Daim, head of the Early Medieval Department of the Germanisches Zentralmuseum, for permitting me to publish the weight and Ute Klatt, head of the Image Archive of the same museum, for sending me the photo of the weight and Jörg Drauschke for sending me the technical info of the weight. I also thank Mrs Remziye Küçük, wife of the late collector, for permitting me to publish these two weights.

6) Germanisches Zentralmuseum Mainz, inv. nº 0.40402.

7) RK 004 (tentative number). 


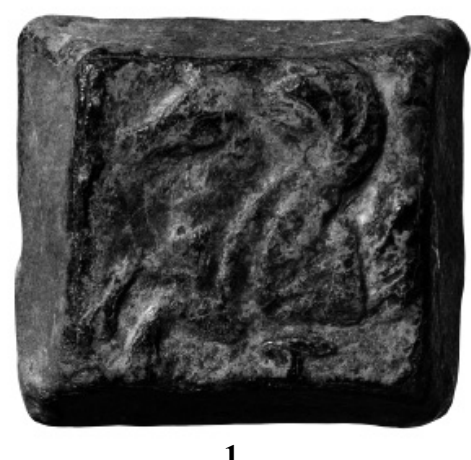

1

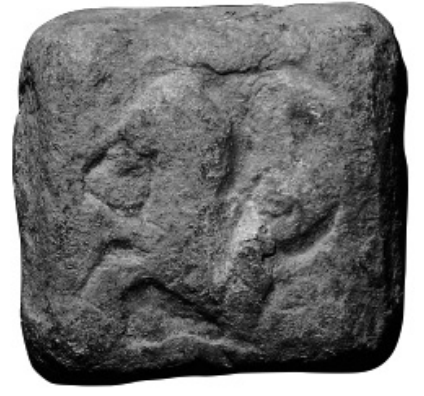

2

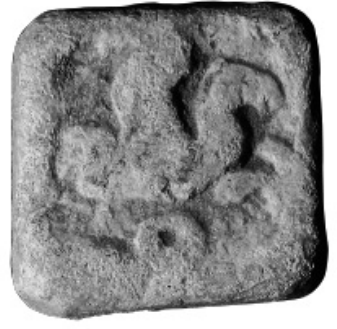

3 inational mark on the weight. But its mass corresponds to an ogdoon, i.e. one-eighth of a mna (mna of $528.8 \mathrm{~g}$ ). This weight was acquired in Tekirdağ in $1990 \mathrm{~s}^{8}$ or later.

The third weight (Fig. 3$)^{9}$ is also square in form: it measures $23 \times 23 \times 8 \mathrm{~mm}$ and weighs $39.5 \mathrm{~g}$. On the obverse is an Hippalectryon again but this time facing right and its head looks like a camel's head due to deformation. Below, a large $\mathrm{O}$ may be either an omicron or rather a wreath. If we assume it as an omicron, then it might be the initial of the denominational name, i.e. ogdoon but its mass does not correspond to an ogdoon ( $1 / 8$ of a $m n a$ ) since it is too light for an ogdoon. Then it may be a wreath. The mass of the present weight corresponds to a one-twelfth of a mna (mna of $474 \mathrm{~g}$ ) but it may be a unit in stater standard, maybe a distateron? (stater of $19.75 \mathrm{~g}$ ). This weight was acquired in Tekirdağ in the 1990s or later.

The main reason attributing the weights abovementioned to Lampsacus is the Hippalectryon since it was the civic badge of that city. It is an hybrid creature with half-horse and half-rooster with wings and tail. Thus, the type on the weights is not a Pegasus but a Hippalectryon as it was stated previously by Weiss ${ }^{10}$. They differ from each other by their peculiar characteristics. Although Hippalectryon, is a civic badge for Lampsacus, this type was also used by other cities in Mysia and Troas ${ }^{11}$. But beside Lampsacus - the nearest candidate to attribute the weights bearing a Hippalectryon is Adramyteum since this creature was used as a common type as well as the owl on the coins of this city ${ }^{12}$. We prefer to attribute the present weights and the weight with Hippalectryon in general to Lampsacus since the Hippalectryon was nearly a constant civic badge of Lampsacus during the Classical and Hellenistic periods.

Only a few weights of Lampsacus survived today. When we compare Lampsacus with Cyzicus, both important cities of the Propontis, one expects more weights of Lampsacus. But, anyway, the survived examples of Lampsacus may help to understand the standard of mna and its subunits. One of the known examples of Lampsacene weights bears the denominational mark $M$ which stands for $\mu v \tilde{\alpha}$ and it weighs $499 \mathrm{~g}^{13}$. This example is important since it bears the denominational mark. The mna of 499 or $500 \mathrm{~g}$ is quite common in the Aegean world. The neighbouring city of Cyzicus also used a mna of $\pm 500 \mathrm{~g}^{14}$. The first weight (Fig. 1) presented in this article is a tetarton, i.e. quarter mna and weighs $122.5 \mathrm{~g}$. Its mass corresponds to the mass of the mna mentioned above. When we multiply $122.5 \mathrm{~g}$ by four we get $490 \mathrm{~g}$. or - vice versa - when we divide $499 \mathrm{~g}$ by four we get $124.75 \mathrm{~g}$; both figures ( $122.5 \mathrm{~g}$ and $124.74 \mathrm{~g}$ ) are quite near to each other and they give a mna of 490-500 $\mathrm{g}$ for Lampsacus ${ }^{15}$. But the hemimnaion examples does not strictly correspond to a mna of 490-500 g since they are lighter. Of the two hemimnaion units, one is $236 \mathrm{~g}^{16}$, another is $237.10 \mathrm{~g}^{17}$; both give a mna of $c a .472 / 474 \mathrm{~g}$. On the other hand, there are also three ogdoons, one is presented here (Fig. 2), the other is in a private col-

8) Since the collector passed away long ago it was impossible to learn the acquisition date or find place of the two weights.

9) RK 008 (tentative number).

10) Weiss 2008: 714.

11) Weiss 2008: 714-715.

12) For the Hippalectryon on the coins of Adramyteum see Fritze 1910: $n^{\text {os } 1-5 ; ~ R o m a ~ N u m i s m a t i c s ~ L t d . ~ A u c t i o n ~ 4: ~ 1487 ; ~ M u ̈ n z e n ~}$ und Medaillen Deutschland GmbH, Auction 30: 327-328; Dr. Busso Peus Nachfolger, Auction 380: 459.

13) Weiss 2008: 713, $\mathrm{n}^{\circ} 1$

14) Weiss 1990: 125 ff; Tekin 2013: 172.

15) Weiss 2008: 715.

16) CPAI Turkey 3: $\mathrm{n}^{\circ} 29$.

17) Weiss 2008: $713, n^{\circ} 2 . h$ 
lection ${ }^{18}$ and another one is in the Pera Museum ${ }^{19}$. While the masses of the first two ogdoons are quite close to each other (66.1 $\mathrm{g}$ and $62.82 \mathrm{~g}$, respectively), the one in Pera Museum ${ }^{20}$ with $56.90 \mathrm{~g}$ is lighter than these two examples. So, while the first two give a mna of $528.8 \mathrm{~g}$ and $502.56 \mathrm{~g}$, the ogdoon in Pera Museum gives a mna of $455.2 \mathrm{~g}$. Although the third weight (Fig. 3) is a 1/12 mna (mna of $474 \mathrm{~g}$ ), the smallest unit of the Lampsacene weights is
$20.65 \mathrm{~g}$ which is in Pera Museum ${ }^{21}$. It is either a $1 / 24$ of a mna (mna of $495.6 \mathrm{~g}$ ) or a stater weight. We may conclude that the mna of Lampsacus was previously about $470-480 \mathrm{~g}$ but the standard was raised to 490-500 $\mathrm{g}$ in time (may be in the Late Hellenistic Period). The three weights in question date to the Hellenistic Period.

Table: A Compilation of the Weights of Lampsacus.

\begin{tabular}{|c|c|c|c|}
\hline Mna & $499 \mathrm{~g}$ & MNA & Weiss 2008, p. $713, \mathrm{n}^{\circ} 1$ \\
\hline Hemimnaion & $237.10 \mathrm{~g}$ & $\mathrm{H}$ & CPAI Turkey $3, \mathrm{n}^{\circ} 29$ \\
\hline Hemimnaion & $236 \mathrm{~g}$ & $\mathrm{H}$ & Weiss 2008, p. $713, \mathrm{n}^{\circ} 2$ \\
\hline Tetarton & $122.5 \mathrm{~g}$ & $\mathrm{~T}$ & Here, Fig. 1 (Mainz) \\
\hline Ogdoon & $66.1 \mathrm{~g}$ & - & Here, Fig. 2 (RK) \\
\hline Ogdoon & $62.82 \mathrm{~g}$ & $\mathrm{O} ?$ & Weiss 2008, p. $713, \mathrm{n}^{\circ} 3$ \\
\hline Ogdoon & $56.90 \mathrm{~g}$ & $\mathrm{O} \Gamma[\Delta \mathrm{O}] ?$ & CPAI Turkey $3, \mathrm{n}^{\circ} 30$ \\
\hline 1/12 mna & $39.5 \mathrm{~g}$ & - & Here, Fig. 3 (RK) \\
\hline $1 / 24$ mna & $20.65 \mathrm{~g}$ & - & CPAI Turkey $3, \mathrm{n}^{\circ} 31$ \\
\hline
\end{tabular}




\section{BIBLIOGRAPHY}

CPAI Turkey 3: O. Tekin, Corpus Ponderum Antiquorum et Islamicorum. Turkey 3. Suna and Inan Kıraç Foundation Collection at the Pera Museum. Part 1. Greek and Roman Weights, Istanbul, 2013.

Fritze, H. v., 1910: "Die vorkaiserlichen Münzen von Adramytion", Nomisma V: 10-24.

Gaebler, H., 1924: "Lampsakenische Parerga", Zeitschrift für Numismatik (1924): 304-314.

Stauber, J., 1996: Die Bucht von Adramytteion, Teil II, Bonn.

Tekin, O., 2013: "Weights of Cyzicus in Athens Numismatic Museum", Anatolia Antiqua XXI: 167-173.

Thompson, M., 1968: "The mints of Lysimachus", in Kraay, C.M. and Jenkins, G.K. (eds.), Essays in Greek
Coinage Presented to Stanley Robinson, Oxford, 1968: 163-182.

- 1991: Alexander Drachm Mints 2: Lampsacus and Abydus, American Numismatic Society, New York.

Weiss, P., 1990: "Marktgewichte von Kyzikos und Hipparchengewichte", in Schwertheim, E. (ed.), Mysische Studien: 117-139.

-2008: "Gewichte Griechischer Stadte I: Byzantion, Lampsakos, Ilion, Alexandria Troas", in Winter, E. (ed.), Vom Euphrat bis zum Bosporus. Kleinasien in der Antike, Festschrift für Elmar Schwertheim zum 65. Geburstag, vol. 2, Bonn. 


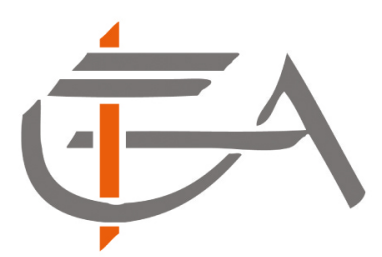

Institut Français

d'Etudes Anatoliennes

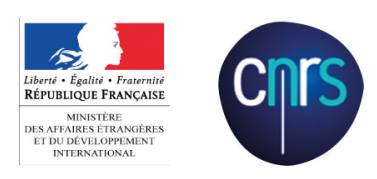

Peinture rupestre préhistorique, Sağlık Köy, près d'Alabanda, Turquie (cliché Suat Ateşlier). 